\title{
The Role of Business Center Alfamart in Improving Student Marketing Competencies
}

\author{
Selviani Putri Anggia \\ Wening Patmi Rahayu \\ Program Studi Pendidikan Tata Niaga Universitas Negeri Malang \\ Didik Indratno, Puji Rahayu, Siti Mutmainah \\ SMKN 1 Turen Kabupaten Malang \\ Email: Selvyananggia2@gmail.com
}

\begin{abstract}
The purpose of this study is to know an overall research, optimization and the role of business center SMKN 1 Turen. The research type is qualitative descriptive. The procedure of Data collection used observation, interview, and documentation. The results show that the design is similar with Alfamart store, the school optimizes it as a real practice place not only the simulation, the infrastructure facilities are complete and promotes in improving psychomotor competence that is Alfaclass students can do arrangement product using FIFO method, operate the cash register, and serving consumer by friendly
\end{abstract}

Keywords: Alfamart Business Center, Psychomotor, Alfaclass

Education is a very important problem in life because education has become a primary need that has an important role in order to foster and build the character and personality of the nation. Through education people can become an educated human being, who has the ability to choose what is good and what is not. Indonesia is a country with large population, does not close any possibility of breaking rules caused more problem. One such problem is the competition in entering the workforce, everyone is competing to get a proper job.

The problem also can be solved by gaining the achievement in the school. In the world of education, is very necessary for the competence given to student, that competence build the provision of knowledge that leads to the formation of attitudes and skill of student. One of the educational units that leads the preparation of labor is Vocational High School (SMK). Therefore, the role of SMK is very important in preparing quality human resources according to current demands. SMK has it own competence field.

Today, some SMK especially majoring in marketing has a business management laboratory or called a business center. Business center is a kind of laboratory or retail business management which is run by people who studying that major. the business center program provides student with marketing experience to train themselves directly in the business world (Heny, 2012).

The activity of SMK student in Marketing is to conduct buying and selling activities directly while in the business center, and student can communicate with people around. Thus of course optimization of business center should be more and more develop. Currently, the SMK's business center sponsored by retail company 
that is supported Alfamart by province and the local Education Office. The business center referred to as a retail laboratory provided to SMK in the form of minimarket that is exactly same as the minimarket outside the school (Yunatan, 2016).

Alfamart gives opportunity to the next generation of the nation especially marketing class to explore as much as possible about retail world to achieve certain competencies. One of the SMK who has Alfamart class program and a business center of Alfamart is SMKN 1 Turen. Cooperation between PT Sumber Alfaria Trijaya with SMKN 1 Turen certainly welcomed, because the form of colaborate on CSR program from PT Sumber Alfaria Trijaya has a positive impact and provide many benefits for schools, especially Alfaclass marketing student in improving competence.

This vocational school is located in Malang Regency, SMKN 1 Turen has Business and Management Major. Business center for student is a place to improve the skills so that students can feel the real world of work (Prabandi, 2015. PT Sumber Alfaria Trijaya inaugurated as a retail education program in the form of Alfamart business center in SMKN 1 Turen on July 28, 2016. Based on the description above, researcher will conduct research on Alfamart business center which the study is devoted to students who are carrying out practice directly.

Competence obtained by students is very diverse, if students are able to carry out various activities then categorize as student that has a competence (Suherman, 2008). However, this study is aimen at students' competence in terms of psychomotor or skill because this research leads to the competence of students' achievement when practicing in business center or business laboratory. Psychomotor domains are closely related to students's skills as they appear from practical activities undertaken by students (Rosa, 2015). Psychomotor domain assessment can be seen from the ability to use existing tools in the business center and how fast they doing it (Rosa, 2015).

Management and optimization of Alfamart business center has a different role for each vocational school. Therefore, researchers want to know how the Alfamart's business center in SMKN 1 Turen able to grow the competence of marketing students by psychomotor aspec.

\section{METHOD}

This research uses qualitative approach and classified in descriptive research. This study aims to abtain some complete and real information according to the fact. In qualitative research, the researchers themselves are the main data collector. In this study, researchers become the key instrument that is very important to find the data.

The location of this research is in the Alfamart's Busniness Center SMKN 1 Turen addressed on Panglima Sudirman Street number 41 Kecamatan Turen, Malang. Researchers use primary and secondary data sources. In collecting data, researchers use several methods of observation, interview and documentation

Data analysis in this study include : data reduction, data presentation and conclusion. Data processing by using checking the validity of the findings which use two ways including doing the double checking carefully and conscientious. So the result can answer precisely. The second is triangulation source which is 
comparing the results of observation by interview and comparing the result with contents of the data that researchers get before. As in the stages of research, researchers divide in three stages of pre-field stage, field stage and data analysis phase.

\section{RESULT \& DISCUSSION}

\section{Result}

Business center that is in SMKN 1 Turen resembles the original form of Alfamart store in the outside of school, ranging from the exterior into interior. SMKN 1 Turen is one of 52 schools that collaborate with PT Sumber Alfaria Trijaya in East Java. Requirements that must be owned by the school is having a marketing department so is SMKN 1 Turen. To simplify the Alfamart party, school also help prepare anything to fulfill the requirement to be collaborated, so that when submitted in the government province, SMKN 1 be avowed worthy to get a cooperation in the form of business center or retail business laboratory. Previously SMKN 1 Turen already has a business center before but the management has not resembled as Alfamart so that SMKN 1 passes in the selection.

The business center at SMKN 1 Turen is a retail business management laboratory that student use for actual practice not as a simulation laboratory or as an application of theory. Marketing department in SMKN 1 Turen has 2 laboratories for learning, one is in the school used by student for simulation, while the business center in a front of the school is Alfamart's business center used for actual practice. Business center owned by SMKN 1 Turen is indeed accordance with the minimart standart or Alfamart store. Service and appearance of Alfaclass students who are practicing are also the same as employees in Alfamart store.

The parties who manage it apart from Alfaclass students are their theachers from marketing department who become mentors in implementing the practice and teacher from accounting department as treasurer, so students can be more disciplined and get maximum benefits with the existence of this business center. However, the Afamart still facilitate. The purpose of this business center for schools is to provide real training for students so that later after they finish the school will not be jobless, because its already has a lot of experience and have a good working mental. Facilities and infrasctructure located in the business center is complete and adequate such as 29 gondola shelves, 2 chillers, 2 freezers, 2 cash register machines, 2 slippers, shopping carts, wagons, full merchandise, CCTV and air conditioner.

Business center is a retail business management laboratory and a practical place that gives a big impact to SMKN 1 Turen especially in marketing department, because they can perform actual various sales and marketing activities beyond the theory.

Those activities undertaken by student in business center that serve consumers, doing the arrangement of merchandise and products, the operation of the cash register. Student perform activities by complying with applicable regulations. That activities start from 7 a.m to 3 p.m. student comply with the rules that apply in the business center, from not allowed playing any gadget at that time, 
arrive late or eat in the checkout area. Student serve customers friendly and courteous manner. There will be 2 student who picket for one day in the business center along with employees or manager. During that time student perform various activities. Students also use all the equipment in the business center such as a cash register.

Student achievement is good enough, the researchers see that the competence in C3 group is theoretically in 12 grade class, but observation of the 10 grade studenta can apply the competence even though they haven't got theoretical learning in the class before. Increase psychomotor began to appear from student activities such as managing products, serving consumers, checking the goods up to operate the cash register.

Students do the activities of arranging the product neatly, without waiting for orders from managers and managers. Structuring the product done in the morning and after the break is completed. Students arrange their products using FIFO (First in First Out) method, which is goods that have long been arranged at the front. Psychomotor competence of students in this activity is a complex movement is the fifth psychomotor level.

Students perform the activities of operating the cashier machine, students operate carefully and thorough, because sometimes at break time the queue in the cashier area is very long. Psychomotor competence of students in this activity that is at the level of guided movement, accustomed and complex is the third, fourth and fifth psychomotor level.

Students serve customers friendly and courteous. Students greeting consumers when consumers enter into the business center, after that the students also say "thank you and welcome back" when the goods delivered to consumers in the cashier area. Psychomotor competence of students in this case is at the level of adjustment and authenticity which is the sixth psychomotor level.

Students obey all rules in the business center from not eating in the cashier area and not playing gadget. Students should not be late to come in the business center at 6.30 a.m. Students wear Alfamart uniform every time practice in the business center. Students also begin to be sensitive to the existing work in the business center, such as cleaning the business center area. Psychomotor competence of students in this case that is at the level of adjustment and authenticity which is the sixth psychomotor level.

\section{Discussion}

This business center referred to business management laboratory, so the center business is a riil laboratory as a form of school's business units, especially for Alfaclass students as a place for real practice to improve a maximum skills.

Business center is a main place of organization that particularly seels the product to get benefit (Prabandi, 2015). Business center not only putting the profit first but also oriented towards training student as a form of direct practice.

Business center in SMKN 1 Turen have a same exterior and interior design as Alfamart store. this laboratory is a result of cooperation provided by PT Sumber Alfaria Trijaya to Vocational School like a minimarket outside the school (Yunatan, 2016). 
Business center used as a laboratory by Alfaclass Student, the student have been taught many things, when comes into internship subject, the Alfamart parties will provide their place across the city and when student finish their school they have a chance to work in Alfarmart without test. Alfamart class is a collaboration program between the company with selected vocation school to educate students become a person that ready to work by referring the rules and certain national education (Yunatan, 2016).

Optimization of business center has been improve even though newly inaugurated in July last year. One of the process to optimalization is in the setting like a real Alfamartshop outside the school so student in business center really works according to the rules. Retail laboratory (business Center) which donated to SMK that serve purchase like a minimarket outside the school (Yunatan, 2016).

Store management doing by the school, especially the teacher from marketing department, the treasurer or accountant from accounting department and has two employees who stand by the Alfaclass student everyday. Management business center comes from school, but the system and facilities are from PT Sumber Alfaria Trijaya (Alfamart). Retail business laboratory fully managed by the school but the facilities remain from Alfamart (Yunatan, 2016).

Busniness center has a very important role for the school, especially ten grade student of Alfaclass. the business center at SMKN 1 Turen actuaaly serves customers, so students can learn many things. Student are given fundamental knowledge about business. How to serve customers well. So that the business center have role to improve the student's competence, because they have been able to do the arrangement the product well, and capable to operate the cash register properly.

The improvement of psychomotor competence of students is seen from various activities related to the students in business center. Psychomotor aspects are seen by observing students' actions and skill while practicing (Rosa, 2015). Psychomotor domains will appear from the students themselves when they gained a particular learning or learning experience (Rosa, 2015).

This business center provides more psychomotor competence compared to cognitive and affective, because students do more practice activities. This psychomotor region is concerned with the skills and abilities of individual actions (Agustina, 2015).

So far, each student has been practicing for 5 times from morning before 7 a.m to 3 p.m. So a lot of psychomotor competence is gained. Six psychomotor classifications from low to high levels. Namely perception, prepared, guided movement, accustomed movement, complex movement, adjustment and authenticity (Ragl, 2011). Students have all of these competencies. Students obey the rules every time the practice means students have passed the second psychomotor level of readiness. Readiness of students is also seen when the students come on time by 6.30 a.m according to the rules, students wear Alfamart unifroms and serve customuers well. Student do not allowed to eat in cashier area and palying gadget. It shows that students are mature both mentally and physically. Included in the second level is psychomotor readiness (Ragil, 2011).

Student doing product structuring activities, also become sensitive to assignment in business center, they have initiative to work without any order, such 
as arranging the product when theres no visitor come into store and fill the shelf immediately if it loose.

Student must use the FIFO method for product arrangement, they check the expired date of the product and they put the most closely expired date at the front. So in this activity students show some psychomotor level that is guided movement, accustomed movement, complex movement (Ragil, 2011) .

Student serve customers friendly and courteous. They look enjoy while serving customers, giving welcome greetings, the student already at the highest psychomotor level that is the sixth adjustment and authenticity.

\section{CONCLUSION \& SUGGESTION}

\section{Conclusion}

Based on the results and discussion about Alfamart Business Center, the researcher finds that Business Center in SMKN 1 Turen is a business center derived from the cooperation between SMKN 1 Turen and PT Sumber Alfaria Trijaya. The business center is a retail business management that use to practice by student.

Regarding the optimization of the business center. Looks very good and continue to be pursued by the school and Alfamart. Business center arranged like the real minimarket outside school. Facilities and infrastructure is very adequate and supportive. Such as cash register, gondola for product structuring, chiller or freezer, slack, wagon, CCTV and air conditioner. The management system is also structured, looking at job description of each parties. The management party is the marketing department assisted by treasurer of accounting. So far, there is no inhibiting factor in business center optimization for student competence. Business centers also play a role in improving competence and preparing student's mental work.

Psychomotor improvements of students already show with the existence of business center, because some student activities are not at lowest level psychomotoric, students have reached at the highest level psychomotoric. Each student has practiced 5 times.

\section{Suggestion}

Researchers provide some suggestions addressed to school about business center are as follows : 1) The school party, especially the business center to add more hours of Alfaclass for 10 grade students to practice in Business Center. Currently, new student practice 5 times. 2) Marketing major expand student activities. Such as promotion activities, make the promotion design and realized it in the business center. 3) Schools can make business center open for public or giving access outside the school, so that students can serve a variety of consumers, not only serving the consumers from a school. So the student's experience about consumer behavior will improve and psychomotor competence can be achieved. 


\section{REFERENCE}

Agustina, D. 2015. Motivasi Belajar dan Hasil Belajar Psikomotor Siswa MTs Sunan Ampel Siman Kepung Kels IX dalam Aktivitas Praktikum IPA. Jurnal Pendidikan dan Pembelajaran, (Online),9(2),(http://cendekia.pusatbahasa.or.id/index.php/cendekia/article /view/47/53

Heny. 2012. Implementasi Kompetensi Kewirausahaan Kepala Sekolah dalam Pengorganisasian Bussines Center "SMK Mart". Journal of Economic Education,(Online),1(2),(http://journal.unnes.ac.id/sju/index.php/jeec/artic le/view/1266), diakses 21 Oktober 2016.

Jaya, H. 2012. Pengembangan Labiratorium Virtual untuk Kegiatan Praktikum dan Memfasilitasi Pendidikan Karakter di SMK. Jurnal Pendidikan Vokasi, (Online),2(1),(http://journal.uny.ac.id/index.php/jpv/article/view/1019), diakses 20 Desember 2016.

Prabandi, E. 2015. Pengaruh Pembelajaran Kewirausahaan Melalui Business Center, Prakerin, dan Latar Belakang Keluarga terhadap Kompetensi Berwirausaha. Jurnal Pendidikan Vokasi, (Online), 5 (1), (http://journal.uny.ac.id/index.php/jpv/article/view/6054), Diakses 7 Mei 2017.

Ragil, Z. 2011. Penerapan Pembelajaran Sains Dengan Pendekatan SETS pada Materi Cahaya untuk Meningkatkan Hasil Belajar Siswa Kelas V SD. Jurnal Pendidikan Fisika Indonesia, (Online), 7, (http://Journal.unnes.ac.id/nju/index.php/JPFI/article/view/1073). Di akses 7 Mei 2017.

Rosa, F. 2015. Analisis Kemampuan Siswa Kelas X pada Ranah Kognitif, Afektif dan Psikomotorik. Jurnal Fisika dan Pendidikan Fisika, (Online), 1 (2), (http:omega.uhamka.ac.id/index.php/omega/article/view/37), diakses 7 Mei 2017.

Utami, N. Pengaruh Sarana dan Prasarana Business Center dan Lingkungan Keluarga Melalui Proses Pembelajaran Kewirausahaan terhadap Minat Berwirausaha Siswa Kelas XI SMK NU Bandar Kabupaten Batang Tahun 2015. Jurnal Pendidikan

Ekonomi, (Online),4(3),(http://journal.unnes.ac.id/sju/index.php/eeaj), di akses 10 Januari 2017.

Suherman, E. 2008. Model Pembelajaran dan Pembelajaran Berorientasi Kompetensi Siswa. Jurnal Pendidikan dan Budaya (Educare),(Online),5(2),(http://jurnal.fkip.unla.ac.id/index.php/educare/arti cle/view/62/62), di akses 7 Mei 2017. 
Yunatan, C. 2016. Pengaruh Corporate Sosial Responsibilty "Alfamart Class" di SMK PGRI 3 Malang terhadap Citra Perusahaan Alfamart. Jurnal E-Komunikasi, (Online), 4(1), (studentjournal.petra.ac.id/index.php/ilmukomunikasi/article/view/4889), diakses $20 \quad$ Oktober 201 
73 Jurnal Pendidikan Bisnis dan Manajemen, Volume 3 Number 1 2017, Page 65 - 72 